\title{
Bacterial Isolates of Urine and their Susceptibility to Antimicrobials
}

\author{
Batool Mutar Mahdi ${ }^{1 *}$, Haneen Basim Khudhur², Mustafa Mohammad Abdul-Hussein ${ }^{2}$ \\ ${ }^{1}$ Department of Microbiology, Al-Kindy College of Medicine, University of Baghdad, Baghdad, Iraq; ${ }^{2}$ Al-Kindy College of \\ Medicine, University of Baghdad, Baghdad, Iraq
}

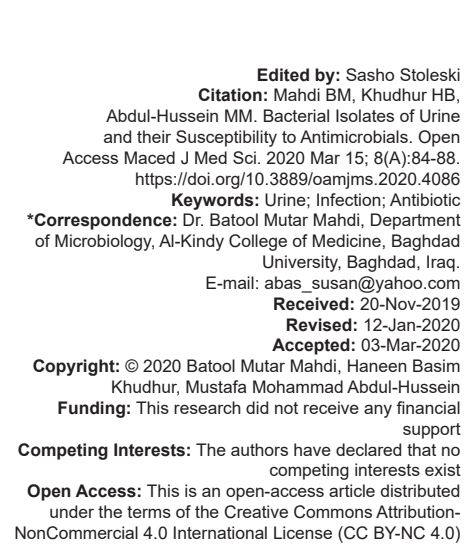

\section{Introduction}

Urinary tract infection (UTI) is a collective term used to describe the microbial invasion of any part of the urinary tract [1]. It is one of the most common bacterial infections in both sexes, with a predilection in females [2], [3]. Antibiotics are often used to prevent and treat these bacterial infections, but some bacteria developed the ability of growing effectively in an antibiotic-rich environment, giving the rise of what's called "antibiotic resistance" [4], [5]. There are several risk factors associated with UTIs such as sex, vaginal infection, antibacterial activity of prostatic fluid, diabetes, personal hygiene, obesity, and genetic susceptibility [6]. The diagnosis is urine culture with the presence of clinical symptoms while antibiotic susceptibility can be measured by disc diffusion, dilution tests, and killing curve [7]. The most common uropathogen is Escherichia coli, which is responsible for $80 \%$ of community acquired and $40 \%$ of nosocomial infections include fecal Gramnegative rods, Klebsiella, Proteus spp., Enterobacter, Serratia, and Pseudomonas aeruginosa and Grampositive cocci including enterococci, other organisms including Candida spp. [7], [8]. Knowing about that is important to ensure high cure and low resistance rates [9], [10]. Meanwhile, antibiotic resistance is rising to dangerously high levels in all parts of the world. The causes of increased antibiotic resistance are overusing, improper prescribing, availability of few new antibiotics, and regulatory barriers [11]. Therefore, the enforcement of antibiotic supervised programs is effective to reduce the chances of bacterial resistance [12]. Without urgent action, we are heading for a post-antibiotic era, in which common infections [13]. Recently, in 2013, the Centers for Disease Control and Prevention published that about 2 million people develop infections with antibiotic-resistant pathogens each year [14]. Looking into the common pathogens and testing their antibiotic susceptibility is of great importance since there is an increase in antibiotic susceptibility in all age groups [15], [16]. Antibiotic resistance is a global and a local crisis in Iraq, affecting hundreds of lives, particularly low socioeconomic or war areas [17]. Nobel laureate Joshua Lederberg put it better nearly 19 years ago when he wrote "The future of humanity and microbes will likely evolve as ... episodes of our wits versus their genes" [18].

This study aims to isolate the bacteria causing UTI and the highest resistance microorganisms with resistance rates to different antibiotics. 


\section{Patients and Methods}

A cross-sectional study consists of 1000 patients referred to Al-Kindy Teaching Hospital for urine culture and antibiotic susceptibility examination from November 2017 to April 2019. The inclusion criteria were patients with dysuria, lion pain, and frequency while the exclusion criteria were congenital renal diseases and patients with tumor of genitourinary system. Ethical approval and permissions to collect samples were obtained from the Al-Kindy College of Medicine and Al-Kindy Teaching Hospital.

Mid-stream urine samples were cultured after a general urine exam on blood and MacConkey agar media to know if there is the growth of bacteria, then incubated aerobically at $37^{\circ} \mathrm{C}$ for $24 \mathrm{~h}$ and extended up to $48 \mathrm{~h}$ in cases of Gran-negative. Identification of isolates was done by a standard method depending on the observation of colony characteristics and antimicrobial susceptibility test was performed by disc diffusion method using MullerHinton agar and choice of antibiotic disks according to the type of isolated bacteria. If there is a growth of the bacteria around disc, this means the bacteria are resistant. The growth in the inhibition zone means that there is a mixed culture of two bacterial species [19].

The results were recorded as susceptible (S), intermediate $(\mathrm{I})$, and resistant $(\mathrm{R})$. The following antibiotics were used: Amikacin, amoxicillin (clavulanic acid), amoxicillin, ampicillin, ampicillin-sulbactam, cefepime, cefixime, cefotaxime, cefoxitin, cefpodoxime, ceftazidime, cephalothin, chloramphenicol, ciprofloxacin, clindamycin, erythromycin, imipenem, lincomycin, nalidixic acid, netilmicin, penicillin, streptomycin, tetracycline, ticarcillin (clavulanic acid), tobramycin, trimethoprim-sulfamethoxazole, vancomycin, aztreonam, gentamicin, piperacillin, rifampicin, ceftriaxone, nitrofurantoin, azithromycin, meropenem, trimethoprim, doxycycline, and levofloxacin.

\section{Statistical analysis}

Data were entered and analyzed using SPSS version 17.0.1 for windows (SPSS, Inc., Chicago, IL). Discrete variables were expressed as frequencies and percentages.

\section{Results}

The study included that 1000 urine samples were obtained from patients with UTI. Their mean ages were $39.5 \pm 0.8$ (range 6 months- 88 years). The results of the urine culture showed that $318(31.8 \%)$ of urine samples were found positive while $682(68.2 \%)$ were negative. Females were more than males (Figure 1); of
667 females, 225 (72.3\%) were found positive while among 333 males, $93(27.92 \%)$ were positive for bacterial infection. The most frequent pathogen was E. coli $(40.5 \%)$ followed by Klebsiella pneumonia $(25.7 \%)$ which together accounted for $66.2 \%$ of the total uropathogens (Table 1 and Figure 2).

Of 41 antibiotics, the ten most frequently used antibiotics were nitrofurantoin, gentamicin, ciprofloxacin, amikacin, cefixime, and ceftriaxone, as demonstrated in Table 2 and Figure 3 . The bacteria that showed the highest resistance rates were $E$. coli and $K$. pneumonia which are the predominant cause of UTIs. The susceptibility and resistance of $K$. pneumonia to some different antibiotics shown in Table 3 and the most common antibiotic that K. pneumonia sensitive to it was amikacin $47(32 \%)$. Regarding E. coli was most susceptible to nitrofurantoin $85(51.2 \%)$, as shown in Table 4.

\section{Discussion}

UTI is a common disease in females more than males which are shown in this study that females held the highest percentage $(72.3 \%)$ over males $(27.7 \%)$; this may be due to the distance between the anus and urethral meatus and moisture content surrounding urethra [6].

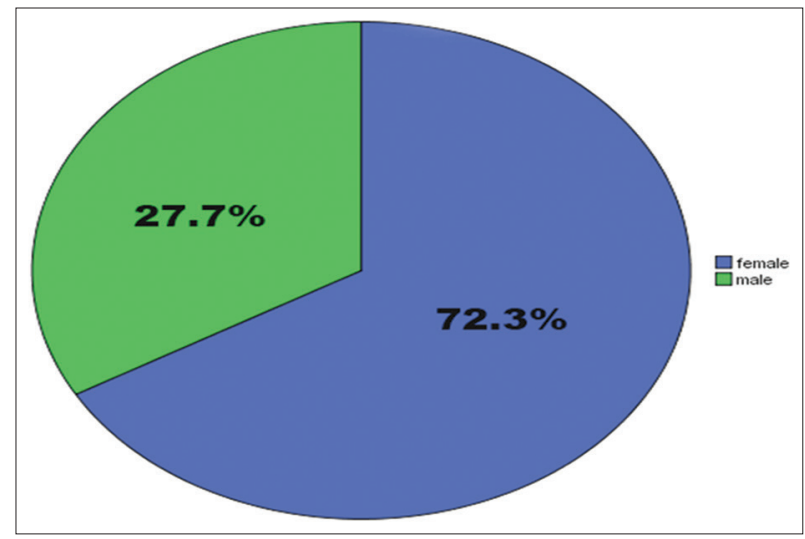

Figure 1: Sex distribution of patients

In this study, $318(31.8 \%)$ urine samples were found positive while $682(68.2 \%)$ were negative, high rates of negative isolates may be due to one or more of several factors that lead to diagnostic inaccuracy which include the collection of first-void urine instead of midstream urine sample [20].

Table 1: Types of isolated bacteria from urine samples

\begin{tabular}{lll}
\hline Bacteria & Frequency & Percent \\
\hline Escherichia coli & 126 & 40.5 \\
Klebsiella pneumonia & 80 & 25.7 \\
Staphylococcus aureus & 22 & 7.1 \\
Streptococcus faecalis & 21 & 6.8 \\
Enterobacter aerogenes & 18 & 5.8 \\
Pseudomonas aeruginosa & 16 & 5.1 \\
Enterobacter cloacae & 10 & 3.2 \\
Streptococcus pyogenes & 8 & 2.6 \\
Streptococcus agalactiae & 4 & 1.3 \\
Proteus vulgaris & 4 & 1.3 \\
Streptococcus gallolyticus & 2 & 0.6 \\
Total & 311 & 100.0 \\
\hline
\end{tabular}


Table 2: Types of tested antibiotics

\begin{tabular}{llll}
\hline Antibiotic & Total uses & $\begin{array}{l}\text { Resistance of all } \\
\text { isolated bacteria \% }\end{array}$ & $\begin{array}{l}\text { Susceptibility of all } \\
\text { isolated bacteria \% }\end{array}$ \\
\hline Nitrofurantoin & 260 & 29.61 & 63.84 \\
Gentamicin & 234 & 25.64 & 64.95 \\
Ciprofloxacin & 198 & 43.65 & 54.54 \\
Amikacin & 164 & 7.31 & 89.63 \\
Cefixime & 127 & 74 & 23.62 \\
Ceftriaxone & 126 & 60.31 & 34.92 \\
Ticarcillin (clavulanic acid) & 111 & 73.87 & 20.72 \\
Rifampin & 96 & 68.75 & 14.58 \\
Aztreonam & 74 & 33.78 & 58.10 \\
Cefepime & 72 & 44.44 & 47.22 \\
\hline
\end{tabular}

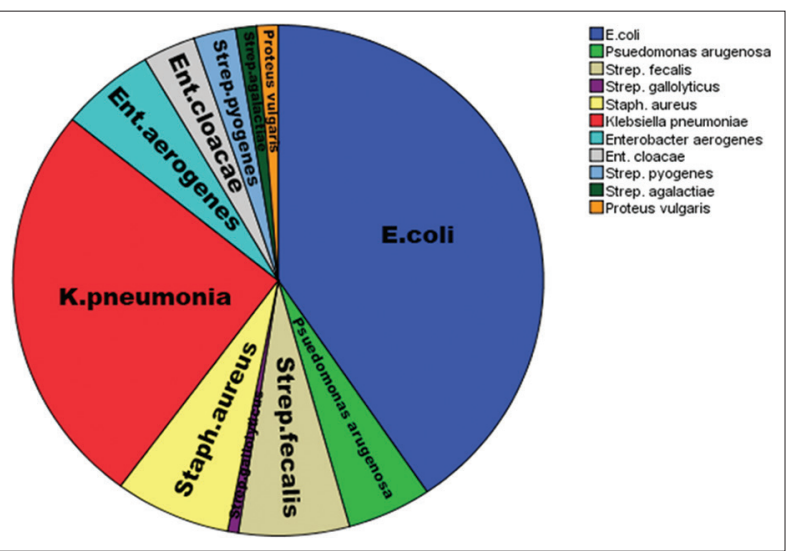

Figure 2: Frequencies of isolated bacteria from urine samples

This study results in accordance with other studies such as Kareem and Rasheed 2011 [21] study, where they obtained 125 (40.19\%) bacteriuria of 311 urine samples in Al-Karkh Surgery Hospital in Baghdad. Other studies that done by Al-Barzinji et al. 2010 found that among 350 patients, the bacterial cultivations revealed positive results for $119(34 \%)$ urine specimens in Hawler and Sulaimani Teaching Hospitals in Kurdistan region which is similar to this study results [22]. In contrast, Najim et al. 2015 recorded a result of $77.27 \%$ bacteriuria from 135 urine isolates in the intensive care unit at Baqubah General Teaching Hospital which was showed higher percentage due to sample size, procedure of collection samples, and quality of patients which they were bedridden [15].

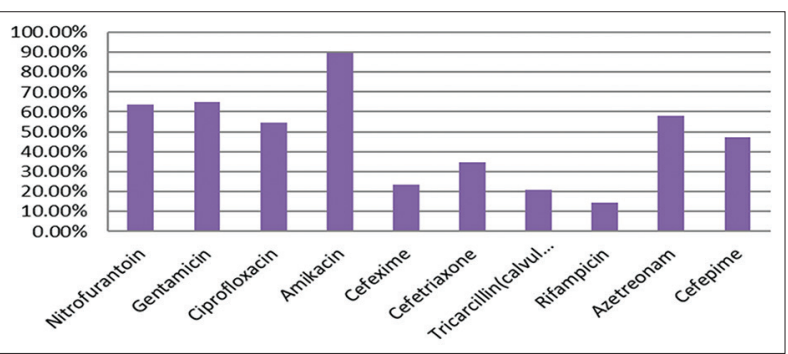

Figure 3: Types of used antibiotics and their susceptibility

This study demonstrated that E. coli $(40.5 \%)$ was the most frequent uropathogen in this study, which is similar to other researches [21], [22], [23], [24]. The second most frequent pathogen in this study was $K$. pneumonia $(25.7 \%)$ which is equivalent to a study done at Al-Yarmouk Teaching Hospital 2010 (30.7\%) [24], in contrary to another study where Proteus spp. was reported as the second most common bacteria which are due to methods used in isolation the bacteria in addition to previous causes mentioned above [25].
Table 3: The susceptibility and resistance of Klebsiella pneumonia to some different antibiotics

\begin{tabular}{lll}
\hline Type of antibiotics & Susceptibility & Resistance \\
\cline { 2 - 2 } & $\mathrm{n}(\%)$ & $17(28.3)$ \\
\hline Gentamicin & $35(23)$ & $5(41.6)$ \\
Amikacin & $47(32)$ & $22(28.5)$ \\
Nitrofurantoin & $39(23.5)$ & $23(26.7)$ \\
Ciprofloxacin & $33(30.5)$ & $29(30.8)$ \\
Cefixime & $7(23.3)$ & $20(26.3)$ \\
Ceftriaxone & $12(27.2)$ & \\
\hline
\end{tabular}

Table 4: The susceptibility and resistance of Escherichia coli to some different antibiotics

\begin{tabular}{lll}
\hline Type of antibiotics & Susceptibility $\mathrm{n}(\%)$ & Resistance $\mathrm{n}(\%)$ \\
\hline Gentamicin & $64(42.1)$ & $23(38.3)$ \\
Amikacin & $69(46.93)$ & $1(8.3)$ \\
Nitrofurantoin & $85(51.2)$ & $14(18.1)$ \\
Ciprofloxacin & $30(27.7)$ & $44(51.1)$ \\
Cefixime & $16(53.3)$ & $36(38.2)$ \\
Ceftriaxone & $23(52.2)$ & $37(48.6)$ \\
\hline
\end{tabular}

Regarding antibiotic susceptibility, nitrofurantoin is a urinary antiseptic that is use in UTI that inhibits various enzymes and damages bacterial DNA [26]. In this study, $29.61 \%$ of all isolated bacteria were resistant to nitrofurantoin and $E$. coli had a higher sensitivity to nitrofurantoin 85 (51.2\%) (Table 4) comparing the result with another study done at Al-Kindy Teaching Hospital in 2016 by Nashtar that found nitrofurantoin resistance was $20 \%$ [27]. Higher resistant rate was obtained by Alhamdany 2015 that found $41.3 \%$ antibiotic resistance [25]. This due to the type of his sample was diabetic patients who suffered from recurrent UTI. On the other hand, Ghaima et al. 2018 obtained nearly similar to the result of this study (29.8\%) [28]. The mechanism of this resistance is due to mutation [29].

The resistance rates of amikacin and gentamicin were $13.2 \%$ and $22.6 \%$, respectively [27]. In this study, K. pneumonia showed the higher sensitivity to amikacin $47(32 \%)$ (Table 3). The cause of this decrease in the usage of amikacin which reduced its resistance. In other studies, it was found that $E$. coli did not produce any resistance against amikacin but $29 \%$ resistance to gentamicin [30]. Other studies done in Karbala by Al-Awwad and Mohsen 2018 showed 1.8\% resistant to amikacin and $38.2 \%$ resistant to gentamicin [31]. Resistance to aminoglycosides developed when a bacterium changes its inner membrane permeability [29].

In this study, some $\beta$-lactam antibiotics showed high resistance rates such as cefixime $74 \%$, ticarcillin (clavulanic acid) $73.87 \%$, and ceftriaxone $60.31 \%$ (Table 2). Al-Samarrai study in Kirkuk 2016 showed a slightly higher resistance in cefixime $79.9 \%$ [32]. However, Al-Naqshbandi et al. 2019 study showed even greater resistance when it is just ticarcillin by itself with Gram-positive bacteria being fully resistant [33]. Furthermore, aztreonam showed greater resistance in Hussein et al. 2019 study in Duhok with $60.91 \%$ resistance to aztreonam [23], could possibly indicate a more resistance in northern Iraq because of the increased antibiotic prescribing.

In this study, $43.65 \%$ of the bacteria were resistant to ciprofloxacin (Table 2). This study results fall just 
between Nashtar 2016 study with $51.1 \%$ resistance and Hussain et al. 2019 study with 33\% resistance in [27], [30]. Meanwhile, Ghaima et al. 2018 study showed 49.4\% resistance [28]. This resistance is caused by a point mutation in the bacterial DNA gyrase subunits [29].

In this study, rifampin had a high resistance of $68.75 \%$, Al-Naqshbandi et al. 2019 study in Erbil showed a similar result of $64.10 \%$ [33].

Totakeabroaderaspect, this study was compared to another study that took place in Kulasekharam, India, 2017; the most common organism isolated overall was $E$. coli $(35.5 \%)$, females $(68.63 \%)$ were more affected than males in this study. The most sensitive antibiotics to almost all organisms were nitrofurantoin and amikacin [34]. While the results differ from a study in Ankara, Turkey 2018, where the most resistant antibiotic was ampicillin, the least resistant was amikacin. This difference may be due to the type of antibiotics frequently prescribed and the sampling population [35], [36], [37], [38].

The increased resistance rates in this study are quite worrisome, which may reflect the extensive use and misuse of prescribed antibiotics by patients and healthcare and high prescribers of antibiotics in general practice [39], [40]. Duration of the treatment and patients' compliance. This overuse could lead to multidrug-resistant strains, with the potential of dissemination within a specific region.

\section{Limitation of the study}

This study was limited by the availability and use of antibiotics in antibiotic susceptibility tests.

\section{Conclusions}

E. coli remains to be the most frequent bacterial uropathogen causing urinary infections. Effective drug may be in a clinical study; in microbiology is only that bacteria were most susceptible to amikacin. $\beta$-lactams have the highest resistance rates, and the most resistance antibiotic in this study is cefixime.

\section{References}

1. Tan CW, Chlebicki MP. Urinary tract infections in adults. Singapore Med J. 2016;57(9):485-90. PMid:27662890

2. Foxman B. The epidemiology of urinary tract infection. Nat Rev Urol. 2010;7(12):653-60.

PMid:21139641

3. Al-Badr A, Al-Shaikh G. Recurrent Urinary Tract Infections
Management in Women: A review. Sultan Qaboos Univ Med J. 2013;13(3):359-67. https://doi.org/10.12816/0003256 PMid:23984019

4. Antibiotic Resistance; 2018. Available from: https://www.who. int/en/news-room/fact-sheets/detail/antibiotic-resistance.

5. Bush L, Schmidt C. Overview of Bacteria Infections MSD Manual Consumer Version. MSD Manual Consumer Version; 2019. Available from: http://www.merckmanuals.com/home/ infections/bacterial-infections/overview-of-bacteria.

6. Foxman B. Urinary tract infection syndromes: Occurrence, recurrence, bacteriology, risk factors, and disease burden. Infect Dis Clin North Am. 2014;28(1):1-3.

PMid:24484571

7. Spicer J. Clinical Microbiology and Infectious Diseases. $2^{\text {nd }}$ ed. London, United Kingdom: Elsevier Health Sciences; 2008.

8. Ghorbani A, Ehsanpour A, Roshanzamir N, Omidvar B Alterations in antibiotic susceptibility of urinary tract infection pathogens. J Nephropathol. 2012;1(1):43-8. https://doi. org/10.5812/jnp.8

PMid:24475385

9. Kollef $\mathrm{MH}$. Optimizing antibiotic therapy in the intensive care unit setting. Crit Care. 2001;5(4):189-95.

PMid:11511331

10. Strålin K. Usefulness of aetiological tests for guiding antibiotic therapy in community-acquired pneumonia. Int $\mathrm{J}$ Antimicrob Agents. 2008;31(1):3-11. https://doi.org/10.1016/j. ijantimicag.2007.06.037 PMid: 17920819

11. Ventola CL. The antibiotic resistance crisis: Part 1: Causes and threats. P T. 2015;40(4):277-83.

PMid:25859123

12. Lee DS, Lee SJ, Choe HS. Community-acquired urinary tract infection by Escherichia coli in the era of antibiotic resistance. Biomed Res Int 2018;2018:7656752. https://doi. org/10.1155/2018/7656752 PMid:30356438

13. Spellberg B, Gilbert DN. The future of antibiotics and resistance: A tribute to a career of leadership by John Bartlett. Clin Infect Dis. 2014;(59 Suppl 2):S71-5. https://doi.org/10.1093/cid/ciu392 PMid:25151481

14. Centres for Disease Control and Prevention. Antibiotic Resistance Threats in the United States, 2013. United States: Centres for Disease Control and Prevention, US Department of Health and Human Services; 2013. Available from: https://www. cdc.gov/drugresistance/pdf/ar-threats-2013-508.pdf. https://doi. org/10.15620/cdc:82532

15. Najim HT, Farhan AA, Athab AM. Bacteriological Study of the bacteria cause urinary tract infection of patients admitted to cardiac care unit at Baqubah general teaching hospital. Diyala J Med. 2018;14:73-83. https://doi.org/10.26505/djm.14013610829

16. Bryce A, Hay AD, Lane IF, Thornton HV, Wootton M, Costelloe C. Global prevalence of antibiotic resistance in paediatric urinary tract infections caused by Escherichia coli and association with routine use of antibiotics in primary care: Systematic review and meta-analysis. BMJ. 2016;352:1939. https://doi.org/10.1136/ bmj.i939 PMid:26980184

17. The Invisible Burden of Antibiotic Resistance in Mosul; 2019 Available from: https://www.msf.org/invisible-burden-antibioticresistance-mosul-iraq?gclid=EAlalQobChMI1ZfP9rCH4gIVzYK yCh1EXgeHEAAYASAAEgJ6iPD_BwE.

18. Lederberg J. Infectious history. Science. 2000;288:287-93. PMid: 10777411

19. LaRocco MT, Franek J, Leibach EK, Weissfeld AS, Kraft CS, Sautter RL, et al. Effectiveness of preanalytic practices on 
contamination and diagnostic accuracy of urine cultures: A laboratory medicine best practices systematic review and meta-analysis. Clin Microbiol Rev. 2016;29:105-47. https://doi. org/10.1128/cmr.00030-15 PMid:26598386

20. LaRocco MT, Franek J, Leibach EK, Weissfeld AS, Kraft CS, Sautter RL, et al. Effectiveness of preanalytic practices on contamination and diagnostic accuracy of urine cultures: A laboratory medicine best practices systematic review and metaanalysis. Clin Microbiol Rev. 2016;29(1):105-47. https://doi. org/10.1128/cmr.00030-15 PMid:26598386

21. Kareem IJ, Rasheed IY. Antibiotic susceptibilities of gram negative aerobic bacteria isolated from urinary tract infections in community. Iraqi J Med Sci. 2011;9:295-300.

22. Al-Barzinji R, Esmahil S, Sulaiman S, Raheem SG. Effect of some antimicrobial agents on isolated bacteria from patients with urinary tract infection in Kurdistan Region. Zanco J Med Sci. 2010;14:61-7.

23. Hussein N, Daniel S, Salim K, Assafi M. Urinary tract infections and antibiotic sensitivity patterns among women referred to Azadi teaching hospital, Duhok, Iraq. Avicenna J Clin Microbiol Infect. 2019;5:27-30.

24. Mohammed AM. Microorganisms isolated from cases of urinary tract infections. Iraqi J Community Med . 2010;23:25-31.

25. Alhamdany $\mathrm{MH}$. Antibiotic susceptibility of bacteria isolated from patients with diabetes mellitus and recurrent urinary tract infections in Babylon Province, Iraq. Med J Babylon. 2018;15:63-8. https://doi.org/10.4103/mjbl.mjbl_16_18

26. Whalen K, Finkel $\mathrm{R}$, Anderson S, Birnbaum A, Carris $\mathrm{N}$, Cogan P. Lippincott Illustrated Reviews: Pharmacology. $6^{\text {th }}$ ed. Philadelphia, PA: Wolters Kluwer; 2015.

27. Nashtar SB. Assessment of antimicrobial susceptibility assessment of antimicrobial susceptibility patterns in urine culture of patients with urinary tract infection. Iraqi Med J. 2018;64:1-5.

28. Ghaima K, Khalaf Z, Abdulhassan A, Salman N. Prevalence and antibiotic resistance of bacteria isolated from urinary tract infections of pregnant women in Baghdad hospitals. Biomed Pharmacol J. 2018;11:1989-94. https://doi.org/10.13005/bpj/1573

29. Gladwin M, Trattler B. Clinical Microbiology Made Ridiculously Simple. $3^{\text {rd }}$ ed. United State of America: MedMaster, Inc.; 2004.
30. Hussain AR, Saleh MB. Determination of phylogenetic groups and antimicrobial susceptibility patterns for Escherichia coli isolated from patients with urinary tract infection. J Educ Pure Sci. 2019;9:71-81. https://doi.org/10.32792/utq. jceps.09.01.08

31. Al-Awwad HA, Mohsen HA. Study the ability of bacteria Escherichia coli to formation of biofilm isolated from patients with urinary tract infections and resistance to antibiotics. J Kerbala Univ. 2018;16:315-9.

32. Alsamarai AM, Ali S. Urinary tract infection in female in Kirkuk city, Iraq: Causative agents and antibiogram. World J Pharm Pharm Sci. 2016;5:261-73.

33. Al-Naqshbandi AA, Chawsheen MA, Abdulqader HH. Prevalence and antimicrobial susceptibility of bacterial pathogens isolated from urine specimens received in Rizgary hospital Erbil. J Infect Public Health. 2019;12(3):330-6. https://doi.org/10.1016/j. jiph.2018.11.005

PMid:30522892

34. Rajendran V, Nepoleon R, Solanke PV, Zailu MS, Valli P. A study on urinary tract infection in a tertiary care hospital. Int $\mathrm{J}$ Adv Med. 2017;4:1401-5. https://doi.org/10.18203/2349-3933. ijam20174292

35. Gunduz S, Uludağ Altun H. Antibiotic resistance patterns of urinary tract pathogens in Turkish children. Glob Health Res Policy. 2018;3:10. https://doi.org/10.1186/s41256-018-0063-1 PMid:29568806

36. Jabba AA. The association between aneamia and urinary tract infection among the pregnant women in Baghdad. J Fac Med Baghdad. 2006;48:267-71.

37. Allah IM, Mutlaq ST. The incidence of lower (UTI) according to age and sex in Ramadi city. J Fac Med Baghdad. 2009;51:289-91.

38. Al-Bayaa YJ. Genitourinary tract infection in diabetic women: Bacteriological study. J Fac Med Baghdad. 2010;52:320-3.

39. Hallsworth M, Chadborn T, Sallis A, Sanders M, Berry D, Greaves F, et al. Provision of social norm feedback to high prescribers of antibiotics in general practice: A pragmatic national randomised controlled trial. Lancet. 2016;387(10029):1743-52. https://doi.org/10.1016/s0140-6736(16)00215-4 PMid:26898856

40. Almeida SR, Lourenço JS, Ciriolo E. This Paper was Commissioned European Monitoring Centre for Drugs and Drug Addiction; 2017. 